\title{
ASSOCIATION BETWEEN BODY COMPOSITION AND \\ FAT INFILTRATION IN THE LUMBAR MULTIFIDUS \\ IN YOUNG ADULTS
}

Original Article

ARTIGO ORIGINAL

ASSOCIAÇÃO ENTRE A COMPOSIÇÃO CORPORAL EA INFILTRAÇÃO DE GORDURA NOS MULTÍFIDOS

Artículo Original

LOMBARESEM ADULTOS JOVENS

\section{ASOCIACIÓN ENTRE LA COMPOSICIÓN CORPORAL Y LA INFILTRACIÓN DE GRASA EN LOS MULTÍFIDOS LUMBARESEN ADULTOS JÓVENES}

\section{Márcia Heloyse Alves Motta' ${ }^{1}$ (ID (Physiotherapist) \\ Tony Meireles Santos ${ }^{1}$ (D) (Physical Education Professional) Geisa Guimarães de Alencar' (ID) (Physiotherapist) \\ Ruanna Ketyllin Gonçalves de Freitas' (iD \\ (Physiotherapist) \\ Gisela Rocha de Siqueira' (ID \\ (Physiotherapist) \\ 1. Universidade Federal de Pernambuco, Recife/PE, Brazil. 2. Universidade Gama e Filho, Rio de Janeiro/RJ, Brazil.}

\section{Correspondence:}

Gisela Rocha de Siqueira Universidade Federal de Pernambuco (UFPE), Physiotherapy Department.

Av. Jorn. Anibal Fernandes, s/n, Cidade Universitária, Recife, $P E$, Brazil. 50740-560.

giselarsiqueira@gmail.com

\begin{abstract}
Introduction: The increase in body fat is a natural and progressive process with aging, allowing fat infiltration in ectopic sites, such as skeletal muscle, which disrupts its function. Objective: To evaluate the association between body composition, fat infiltration into the low back multifidus muscles, and history of low back pain. Methods: This is a transversal and qualitative study that included young adult subjects of both sexes, and excluded individuals with neurological and musculoskeletal disorders and pregnant women. Fat infiltration into the multifidus and cross section area by magnetic resonance imaging; body composition by Dual-energy $X$-ray absorptiometry (DXA), and physical activity level determined by the International Physical Activity Questionnaire (IPAQ) were evaluated. The sample was divided by sex and. Pearson and Spearman's correlation and stepwise linear regression were performed. For this study, a $p<0.05$, a level of significance of $5 \%$ and confidence interval of $95 \%$ were adopted. Results: Thirty-two individuals were evaluated ( $59.37 \%$ women; $40.63 \%$ men). There was a correlation between fat percentage and total cross-sectional area ( $\left(\mathrm{CSA}_{\text {total) }}(r=0.525 ; p=0.021)\right.$, in women, and with lean abdominal mass $(r=-0.648 ; p=0.017)$ and Body Mass Index (BMI) $(r=-0.644 ; p=0.018)$ in men. There was also an association, in women, between fat percentage and cross section area $\left(R^{2}=0.275 ; p=0.021 ; C l=0.364-3.925\right)$ and, in men, with lean abdominal mass $\left(R^{2}=0.420\right.$; $\mathrm{p}=0.017$; Cl:-9.981- $[-1.235])$. Conclusion: There was correlation between fat percentage in the multifidus and CSA in women, and lean abdominal mass and BMI in men. There was also an association between fat percentage and cross section area in women, and lean abdominal mass in men. However, there was no evidence of any correlation between pain and low back dysfunction. Level of evidence I; Diagnostic studies - Investigating a diagnostic test.
\end{abstract}

Keywords: Body composition; Adipose tissue; Paraspinal muscles; Magnetic resonance imaging.

\section{RESUMO}

Introdução: O aumento da gordura corporaléum processo natural e progressivo com a idade, propiciando a infiltração de gordura em locais ectópicos, como por exemplo, na musculatura esquelética, o que prejudica sua função. Objetivo: Avaliar a associação entre a composição corporal e a infiltração de gordura nos músculos multífidos lombares eo histórico de dores lombares. Métodos: Estudo transversal e quantitativo em que foram incluídos adultos jovens de ambos os sexos e excluidos indivíduos com distúrbios neurológicos, musculoesqueléticos e grávidas. Avaliou-se a infiltração de gordura nos multífidos e a área de seç̧ão transversa por meio de ressonância magnética; a composição corporal por meio de Absorciometria com raios-X de Dupla Energia (DXA) e o nível de atividade física através do Questionário Internacional de Atividade Física (IPAQ). A amostra foi dividida por sexo e feita sua respectiva caracterização, correlação de Pearson e Spearman e regressão linear stepwise. Foi adotado o valor de $p<0,05$, nível de significância de $5 \%$ e intervalo de confiança de 95\%. Resultados: Foram avaliados 32 individuos (59,37\% mulheres; 40,63\% homens). Houve correlação entre o percentual de gordura e a área de secção transversa total (AST tota) $(r=0,525 ; p=0,021)$, nas mulheres, e com a massa magra abdominal ( $r=-0,648 ; p=0,017)$ el Indice de Massa Corporal (IMC) $(r=-0,644 ; p=0,018)$ nos homens. Eassociação, nas mulheres, entre o percentual de gordura e a área de seç̧ão transversa $\left(R^{2}=0,275 ; p=0,021 ; I C=0,364\right.$ - 3,925) e, nos homens, com a massa magra abdominal $\left(R^{2}=0,420 ; p=0,017 ; \mid C:-9,981-[-1,235]\right)$. Conclusão: Encontrou-se correlação entre o percentual de gordura nos multífidos e a AST, nas mulheres, e com a massa magra abdominal e IMC para os homens, além da associação entre o percentual de gordura e a área de secção transversa, para as mulheres, e com a massa magra abdominal para os homens. Entretanto, não foi evidenciada nenhuma correlação com dor e disfunções na coluna lombar. Nível de evidência l; Estudos diagnósticos - Investigação de um exame para diagnóstico.

Descritores: Composição corporal; Tecido adiposo; Músculos paraespinais; Ressonância magnética.

\section{RESUMEN}

Introducción: El aumento de la grasa corporal es un proceso natural y progresivo con la edad, propiciando la infiltración de grasa en lugares ectópicos, como, por ejemplo, en la musculatura esquelética, lo que perjudica su función. Objetivo: Evaluar la asociación entre la composición corporal y la infiltración de grasa en los músculos multífidos 
lumbares y el historial de dolores lumbares. Métodos: Estudio transversal y cuantitativo en el que fueron incluidos adultos jóvenes de ambos sexos, y excluidos individuos con disturbios neurológicos, musculoesqueléticos y gestantes. Se evaluó la infiltración de grasa en los multífidos y el área de sección transversa por medio de resonancia magnética; la composición corporal por medio de Absorciometría con rayos X de Doble Energía (DXA) y el nivel de actividad física a través del Cuestionario Internacional de Actividad Física (IPAQ). La muestra fue dividida por sexo y fue hecha su respectiva caracterización, correlación de Pearson y Spearman y regresión lineal stepwise. Fue adoptado el valor de $p$ $<0,05$, nivel de significancia de 5\% e intervalo de confianza de $95 \%$. Resultados: Se evaluaron 32 individuos (59,37\% mujeres, 40,63\% hombres). Hubo correlación entre el porcentaje de grasa y el área de sección transversa (AST tota) ( $r$ $=0,525, p=0,021)$, en las mujeres, y con la masa magra abdominal $(r=-0,648, p=0,017)$ e Indice de Masa Corporal (IMC) $(r=-0,644, p=0,018)$ en los hombres, y asociación, en las mujeres, entre el porcentaje de grasa y el área de sección transversa $\left(R^{2}=0,275 ; p=0,021 ; / C=0,364-3,925\right)$ y, en los hombres, con la masa magra abdominal $\left(R^{2}=0,420 ; p=\right.$ 0,017; IC: -9,981-[-1,235]). Conclusión: Se encontró correlación entre el porcentaje de grasa en los multífidos y la AST, en las mujeres, y masa magra abdominal e IMC para los hombres, además de la asociación entre el porcentaje de grasa y el área de sección transversa, para las mujeres, y con la masa magra abdominal para los hombres. Entretanto, no fue evidenciada ninguna correlación con dolory disfunciones en la columna lumbar. Nivel de evidencia l; Estudios diagnósticos - Investigación de un examen para diagnóstico.

Descriptores: Composición corporal; Tejido adiposo; Músculos paraespinales; Resonancia magnética.

\section{INTRODUCTION}

The fat deposition in interleaved adipocyte among the muscular fiber feature the fat infiltration, the intramuscular adipose tissue (TAl) ${ }^{1,2}$. Among the factor that can lead to TAl, may be: female, because they have a physiological higher percentage of fat; age, because the misfunction of lipidic metabolism; and the body composition, because the excess of free floating fat ${ }^{1,3-6}$.

The TAI results in decrease of strength production and muscular mass, consequently, function decrease ${ }^{1,3}$, as relation of a transverse section area decrease, although there are controversial researches these alterations are commonly reported in this musculature ${ }^{1,3,7,8}$. At lumbar spine musculature, the lumber multifidus (LM) shows higher predisposition for infiltration and like one of the main stabilization muscle of lumber spine it may result in lumbar pain ${ }^{2,9}$.

The studies focus in female elderly, rare among adult population. In this sense, this study aims to evaluate the association between fat infiltration percentage in lumbar muscles, the body composition and history of pain and lumbar spine misfunction in young adults of both sexes.

\section{METHODS}

\section{Study type and Sample}

Transversal and quantitative study, developed at Recife/PE-Brazil, from September of 2016 to march of 2017, attached to Universidade Federal de Pernambuco (UFPE) and with the approval of this university Committee of Etic and Research (Advice Number: 1.479.824). The participation of the study was ensured by reading and signing an Informed Consent (IC)

There was included subjects young adults from both genders, with and without lumbar pain and excluded the subjects with neurological, musculoskeletal (fractures, abnormalities, trauma history or spine surgery), pregnant, body with metal pieces and claustrophobic history. The sample was composed by 32 volunteers stratified by gender.

\section{Observational Desing:}

The evaluation was performed over two days and all of them made over the first day, except the fat infiltration evaluation, performed at the same week of the first gathering.

Fat infiltration and Multifidus CSA: through magnetic resonance (Signa HDxt 1.5T - GE Healthcare, Wisconsin, United States), in axial T1, with cutting thickness of $5 \mathrm{~mm}$ (Figure 1).

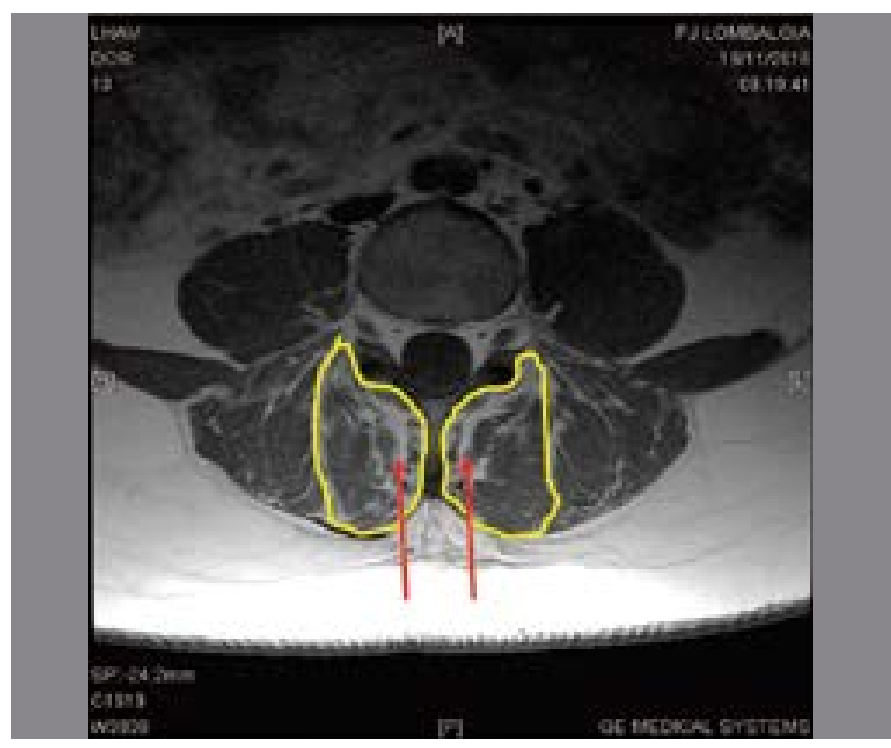

Figure 1. Axial T1-weighted image shows the lumbar multifidus in L5. The dashed line delimits the multifidus lumbar muscle, the arrows point to the fat infiltration.

It was standardized for analysis the images that correspond with the superior edge of L5 and observed with software ImageJ 1.50i (National Institute of Health, USA). It was measured a. the total cross-sectional area $\left(C S A_{\text {total }}\right)$, that comprehends the muscle and the fat inlfiltration; $b$. the fat-free cross-sectional area $\left(\mathrm{CSA}_{\text {fatfree }}\right)$, with the muscular mass; $\mathrm{c}$. the fat cross-sectional area $\left(\mathrm{CSA}_{\mathrm{fat}}\right)$, muscle fat infiltration area. Them, it was quantified the multifidus fat percentage (Multifidus fat percentage $=$ $\left.\mathrm{CSA}_{\mathrm{fat}} / \mathrm{CSA}_{\text {total }} \times 100\right)$ by Color Threshold ${ }^{7}$ method.

Body Composition. It was evaluated the percentage of body and abdominal fat, lean body and abdominal mass and free-fat mass through Double Energy Radiologic Absormetry (DXA) - Lunar Prodigy Primo (GE Medical Systems Lunar, Wisconsin, United States).

Physical activity level. It was used the International Physics Activity Questionnaire (IPAQ), short way, self-applied and referring to the last week $^{10}$. To determine the weekly energy expenditure, it was attributed the value of Metabolic Equivalent Estimate (MET) for each activity (Walk: 3,3 MET; moderate: 4 MET; vigorous: 8 MET) and multiplied by the frequency and duration in minutes ${ }^{11}$. For the weekly caloric expenditure the MET weekly value was multiplied by the weight and divided by $60 \mathrm{~min}^{11}$. 
History of lumbar pain. It was investigated the occurrence of lumbar pain in the last three months and applied the Oswestry Functional Index (IFO) to evaluate the pain and the intensity by the time of gathering ${ }^{12}$.

\section{Statistical Analysis}

It was performed the Shapiro-Wilk test to verify the normality of variables. Then, to compare the averages between male and female was used the Independent Samples t-Test for the normal variables and Mann-Whitney for the outside normality, beside the exactly test of Fisherfor categoric variables.

It was applied the Pearson Correlation, to normal variables and Spearman, to variables outside normality. The results of correlation were classifieds as weak $(<0.4)$, moderate $(0.4-0.7)$ and strong $(>0.7)^{13}$. Then, it was applied the stepwise multiple linear regression between multifidus fat percentage and the predicted variables. The collected data were tabulated and processed by the software Statistical Package for the Social Sciences (SPSS), 22.0 version. It was adopted the $p$-value $<0.05$ for all analysis.

\section{RESULTS}

The research was made with 32 volunteers of which $59,37 \%$ women ( $n=19), 40,63 \%$ men, with characterization between groups for anthropometric measures, body composition, multifidus CSA and physical activity level presented in Table 1.

Regarding lumbar pain, $65,6 \%$ ( $n=21$ ) of the volunteers reported any episode in last three months, more frequently between women $(71.43 \%$; $n=15)$, comparing to men (28.57\%; $n=6)$. However, at the gathering time, only $37.5 \%(n=12)$ reported lumbar pain with higher occurrence in women (75\%; $n=9)$ comparing to men (25\%; $n=3)$ and pain intensity average of $1,2( \pm 0.389)$ and 1 , for women and men, respectively. $25 \%(n=8)$ of the volunteers showed musculoskeletal disfunction of the lumbar spine, more frequently in men (75\%; $n=6)$ comparing to women $(25 \%$; $n=2)$.

For statistical analysis of correlation and association there was chosen the left multifidus. Regarding multifidus fat percentage there was noticed a positive moderate correlation $(r=0.525 ; p=0.021)$ with $C S A_{\text {total }}$ of the multifidus for women. A negative moderate correlation between the quantity of lean abdominal mass $(r=-0.648 ; p=0.017)$ and the body mass index (BMI) ( $r=-0.644 ; p=0.018)$ (Table 2).

For men, the regression linear pattern correlated $42 \%$ of the data, with $F$ test ( $F=7.967)$, used to check the model suitability, showed p-value of 0.017 and standard combings of 1.489 to 2.114 (Table 3).

For women, the regression linear pattern correlated $27.5 \%$ of data variability, with test $F(F=6.456)$, showing $p$-value of 0.021 and standard combings of -1.428 to 2.484 (Table 4).

Table 2. Correlation between the multifidus fat percentage and anthropometric measurements, body composition, multifidus CSA and physical activity.

\begin{tabular}{|c|c|c|c|c|}
\hline \multirow{3}{*}{ Variables } & \multicolumn{4}{|c|}{ Multifidus fat percentage } \\
\hline & \multicolumn{2}{|c|}{ Female $(n=19)$} & \multicolumn{2}{|c|}{ Male $(n=13)$} \\
\hline & $r$ & P-value & $r$ & P-value \\
\hline Age & 0.097 & 0.692 & -0.096 & 0.754 \\
\hline Weight & 0.329 & 0.17 & -0.538 & 0.058 \\
\hline Height & 0.316 & 0.187 & -0.006 & 0.985 \\
\hline $\mathrm{BMI}$ & 0.225 & 0.353 & $-0,644$ & $0.018^{*}$ \\
\hline WC & 0.23 & 0.344 & -0.527 & 0.065 \\
\hline WHR & 0.072 & 0.769 & -0.362 & 0.224 \\
\hline Body fat & 0.232 & 0.339 & -0.45 & 0.123 \\
\hline Abdominal fat & 0.287 & 0.234 & -0.405 & 0.169 \\
\hline Lean body mass & 0.216 & 0.374 & -0.385 & 0.194 \\
\hline Lean abdominal mass & 0.294 & 0.222 & -0.648 & $0.017^{*}$ \\
\hline Fat-free mass & 0.214 & 0.38 & -0.369 & 0.214 \\
\hline Multifidus total CSA & 0.525 & $0.021^{*}$ & -0.092 & 0.764 \\
\hline Multifidus fat-free CSA & -0.09 & 0.714 & -0.354 & 0.235 \\
\hline \multicolumn{5}{|l|}{ IPAQ } \\
\hline Energy expenditure & -.120 & .626 & 0.178 & 0.56 \\
\hline Caloric expenditure & -.141 & .566 & 0.15 & 0.624 \\
\hline Pain intensity (0-5) & .439 & .060 & -0.095 & 0.758 \\
\hline
\end{tabular}

r: Pearson correlation; BMI: Body Mass Index; WC: Waist circumference; WHR: Waist-hip ratio; CSA: Crosssectional area; IPAQ: International Physical Activity Questionnaire; * $\mathrm{p}<0.05$

Table 3. Regression between the multifidus fat percentage and the abdominal lean mass in males.

\begin{tabular}{c|c|c|c|c}
\hline \multirow{2}{*}{ VARIABLES } & \multicolumn{4}{|c}{ Multifidus fat percentage } \\
\cline { 2 - 5 } & Coefficient & Standard error & $\mathrm{Cl}$ & P-value \\
\hline Intercept & 38.188 & 7.558 & $21.552 ; 54.824$ & $<0.001^{*}$ \\
\hline Lean abdominal mass & -5.608 & 1.987 & $-9.981 ;-1.235$ & $0.017^{*}$ \\
\hline Adjusted $\mathrm{R}=0.420 ; \mathrm{P}=0.017 ;{ }^{*} \mathrm{p}<0.05 ; \mathrm{Cl}$ Confidence Interval of $95 \%$ &
\end{tabular}

Table 1. Baseline participant characteristics related to anthropometric measurements, body composition, multifid CSA and physical activity.

\begin{tabular}{|c|c|c|c|c|c|c|c|}
\hline \multirow{3}{*}{ VARIABLES } & & & \multicolumn{4}{|c|}{ Gender } & \multirow[b]{3}{*}{ P-value ${ }^{a}$} \\
\hline & \multicolumn{2}{|c|}{$\begin{array}{l}\text { Total sample } \\
\quad(n=32)\end{array}$} & \multicolumn{2}{|c|}{$\begin{array}{c}\text { Female } \\
(n=19)\end{array}$} & \multicolumn{2}{|c|}{$\begin{array}{c}\text { Male } \\
(n=13)\end{array}$} & \\
\hline & Media & SD & Media & SD & Media & SD & \\
\hline Age (yr) & 25.97 & \pm 2.148 & 25.74 & \pm 2.377 & 26.31 & \pm 1.797 & 0.469 \\
\hline Weight (kg) & 66.775 & \pm 14.941 & 60.026 & \pm 11.166 & 76.638 & \pm 14.566 & $0.001^{*}$ \\
\hline Height $(\mathrm{cm})$ & 167.61 & \pm 8.582 & 162.45 & \pm 4.746 & 175.15 & \pm 7.255 & $<0.001^{*}$ \\
\hline $\mathrm{BMI}\left(\mathrm{kg} \cdot \mathrm{m}^{-2}\right)$ & 23.554 & \pm 4.122 & 22.716 & \pm 4.048 & 24.779 & \pm 4.071 & 0.168 \\
\hline WC $(\mathrm{cm})$ & 80.453 & \pm 12.993 & 76.763 & \pm 11.802 & 85.846 & \pm 13.196 & 0.05 \\
\hline WHR & 0.79 & \pm 0.715 & 0.76 & \pm 0.660 & 0.835 & \pm 0.553 & $0.002^{*}$ \\
\hline Body fat percentage (\%) & 32.9 & \pm 8.908 & 37.278 & \pm 7.141 & 26.5 & \pm 7.333 & $<0.001^{*}$ \\
\hline Abdominal fat percentage (\%) & 32.221 & \pm 11.748 & 34.926 & \pm 11.412 & 28.269 & \pm 11.520 & 0.117 \\
\hline Lean body mass $(\mathrm{Kg})$ & 42.886 & \pm 10.432 & 35.718 & \pm 4.558 & 53.361 & \pm 7.055 & $<0.001^{*}$ \\
\hline Lean abdominal mass (Kg) & 3.005 & \pm 0.778 & 2.493 & \pm 0.295 & 3.753 & \pm 0.642 & $<0.001^{*}$ \\
\hline Fat-free mass (Kg) & 45.243 & \pm 10.711 & 37.903 & \pm 4.710 & 55.97 & \pm 7.293 & $<0.001^{*}$ \\
\hline \multicolumn{8}{|l|}{ Multifidus total CSA $\left(\mathrm{cm}^{2}\right)$} \\
\hline Left & 11.4781 & \pm 2.646 & 10.656 & \pm 2.276 & 12.679 & \pm 2.771 & $0.031^{*}$ \\
\hline Right & 11.323 & \pm 2.400 & 10.551 & \pm 2.054 & 10.356 & \pm 1.931 & $0.025^{*}$ \\
\hline \multicolumn{8}{|l|}{ Multifidus fat-free CSA $\left(\mathrm{cm}^{2}\right)$} \\
\hline Left & 8.947 & \pm 2.329 & 7.872 & \pm 1.515 & 10.519 & \pm 2.462 & $0.001^{*}$ \\
\hline Right & 8.941 & \pm 2.121 & 7.972 & \pm 1.680 & 10.356 & \pm 1.931 & $0.001^{*}$ \\
\hline \multicolumn{8}{|l|}{ Multifidus fat CSA $\left(\mathrm{cm}^{2}\right)$} \\
\hline Left & 2.53 & \pm 1.221 & 2.783 & \pm 1.415 & 2.159 & \pm 0.775 & 0.159 \\
\hline Right & 2.382 & \pm 0.996 & 2.578 & \pm 1.015 & 2.096 & \pm 0.931 & 0.183 \\
\hline \multicolumn{8}{|l|}{ Multifidus fat percentage (\%) } \\
\hline Left & 21,885 & \pm 8.839 & 25.134 & \pm 9.304 & 17.137 & \pm 5.555 & $0.009^{*}$ \\
\hline Right & 21.085 & \pm 7.876 & 24.213 & \pm 7.866 & 16.512 & \pm 5.410 & $0.005^{*}$ \\
\hline \multicolumn{8}{|l|}{ IPAQ } \\
\hline Energy expenditure (MET-min/sem) & 1757.406 & \pm 1898.803 & 1550.789 & \pm 1243.702 & 2059.384 & \pm 2612.950 & 0.097 \\
\hline Caloric expenditure (Kcal/min-sem) & 2014.187 & \pm 2443.223 & 1607.038 & \pm 1381.830 & 2609.251 & \pm 3451.164 & 0.94 \\
\hline
\end{tabular}


Table 4. Regression between the multifidus fat percentage and the multifidus cross-sectional area in females.

\begin{tabular}{c|c|c|c|c}
\hline \multirow{2}{*}{ Variables } & \multicolumn{4}{|c}{ Multifidus fat percentage } \\
\cline { 2 - 5 } & Coefficient & Standard error & $\mathrm{Cl}$ & P-value \\
\hline Intercept & 2.284 & 9.185 & $-17.095 ; 21.664$ & 0.807 \\
\hline $\mathrm{CSA}_{\text {Total }}$ & 2.144 & 0.844 & $0.364 ; 3.925$ & $0.021^{*}$ \\
\hline Adjusted $\mathrm{R}=0.275 ; \mathrm{P}=0.021 ; * \mathrm{*}<0.05 ; \mathrm{CSA}_{\text {Total }}$ Total cross-sectional area; $\mathrm{Cl}$ : Confidence Interval of $95 \%$.
\end{tabular}

\section{DISCUSSION}

There was noticed a moderate correlation and positive association between multifidus fat percentage and CSA in women and negative moderate correlation among BMl and lean abdominal mass in men. However, was not found correlation between pain and disfunction in lumbar spine.

Men got higher averages of anthropometric measures and higher values related to lean mass both body and abdominal and free-fat body mass as observed by another studies ${ }^{14-17}$. As well as muscle CSA was higher too ${ }^{18,19}$. In women, the percentage of superior body fat match the expected physiological result for this population 20,21 and showed in the National Health and Nutrition Examination Survey (NHANES) study with evaluation of body composition using DXA ${ }^{19,22}$. Like the fat percentage in multifidus that also follow the total body distribution in women ${ }^{3,15}$

In men, the fat percentage in lumbar multifidus negatively correlated with lean abdominal mass as showed by another studies ${ }^{14,22-24}$, therefore we estimate the lean circumscribed mass to the lumbar multifidus practice higher influence over the fat percentage than the fat related measures and we should evaluate it to investigate fat infiltration.
Although the lumbar multifidus fat (ML) has presented correlation with $\mathrm{BMI}$ in different thigh muscles ${ }^{24,25}$ and none correlation for paravertebral muscles ${ }^{25}$, in LM we found negative and moderate correlation. As the measure of BMI includes lean mass, we presume it influences the relation between these too variables.

In women there was correlation and association between fat multifidus percentage and $\mathrm{CSA}_{\text {total, }}$ estimating this relation with the multifidus area is due the higher space available for intramuscular fat deposition. These findings diverge from a study made in elderly that showed decrease of CSA total $^{26,27}$, however, this decrease can be due an natural reduction of muscular mass in elderly ${ }^{5}$.

The limitations of this study refer to the absence of investigation of others factors as protein supplementation and vitamin D concentration, directly attached to adipocyte deposition and muscle function evaluation.

\section{CONCLUSION}

It was evidente association between LM fat percentage and CSA in women, suggesting that CSA may increase due the fat infiltration present in LM. In men the LM fat percentage was inversely associated with lean mass, leading to consider it as main factor in young adults fat infiltration presence.

It is suggested that investigations may be performed to make the findings more accessible like adipometer and bioimpedance and ultrasound, even golden pattern, magnetic resonance and DXA are high cost gadgets.

All authors declare no potential conflict of interest related to this article

AUTHORS' CONTRIBUTIONS: Each author made significant individual contributions to this manuscript. MHAM (0000-0003-2900-5895)*: data gathering, statistical analysis, writing the article, review of the article, intellectual concept of the article and production of the entire research project; TMS (0000-0002-5242-0117)*: data analysis and review of the article; GGA (0000-0002-1240-135X)*: data gathering, data analysis, data review and article review; RKGF (0000-0003-2705-9670)*: data gathering, writing the article, review of the article and the entire intellectual concept of the article; GRS (0000-0003-4520-1175)*: statistical analysis, writing the article, review of the article, intellectual concept of the article and all research project production. *ORCID (Open Researcher and Contributor ID).

\section{REFERENCES}

1. Delmonico MJ, Harris TB, Visser M, Park SW, Conroy MB, Velasquez-Mieyer P, et al. Longitudinal study of muscle strength, quality, and adipose tissue infiltration. Am J Clin Nutr. 2009;90(6):1579-85.

2. Hadar H, Gadoth N, Heifetz M. Fatty replacement of lower paraspinal muscles: normal and neuromuscular disorders. AJR Am J Roentgenol. 1983;141(5):895-8.

3. Zamboni M, Rossi AP, Fantin F, et al. Predictors of ectopic fat in humans. Curr Obes Rep. 2014;3(4):404-13.

4. Fortin M, Videman T, Gibbons LE, Battié MC. Paraspinal muscle morphology and composition: a 15-yr longitudinal magnetic resonance imaging study. Med Sci Sport Exerc. 2014;46(5):893-901.

5. Moore $C D$, Craven $B C$, Thabane L, Laing AC, Frank-Wilson AW, Kontulainen $S A$, et al. Lower-extremity muscle atrophy and fat infiltration after chronic spinal cord injury. J Musculoskelet Neuronal Interact. 2015;15(1):32-41.

6. Vidt ME, Santago AC, Tuohy CJ, Poehling GG, Freehill MT, Kraft RA, et al. Assessments of fatty infiltration and muscle atrophy from a single magnetic resonance image slice are not predictive of 3-dimensional measurements. Arthroscopy. 2016;32(1):128-39.

7. Wan Q, Lin C, Li X, Zeng W, Ma C. MRI assessment of paraspinal muscles in patients with acute and chronic unilateral low back pain. Br J Radiol. 2015;88(1053):20140546.

8. Fortin M, Macedo LG. Multifidus and paraspinal muscle group cross-sectional areas of patients with low back pain and control patients: a systematic review with a focus on blinding. Phys Ther. 2013;93(7):873-88.

9. de Siqueira GR, da Silva GAP. Alterações posturais da coluna e instabilidade lombar no indivíduo obeso. Fisioter Mov. 2011 jul/set;24(3):557-66

10. Matsudo S, Araújo T, Matsudo V, Andrade D, Andrade E, Oliveira LC, et al. Questionário Internacional de Atividade Física (IPAQ): estudo de validade e reprodutibilidade no Brasil. Rev Bras Ativ Fis Saude. 2001;6(2):5-18.

11. IPAQ Research Committee. Guidelines for data processing and analysis of the International Physical Activity Questionnaire ( IPAQ ) - short and long forms; 2005. Disponível em: <https://docs.google $\mathrm{com} /$ viewer?a=v\&pid=sites\&srcid=ZGVmYXVsdGRvbWFpbnx0aGVpcGFxfGd4OjEONDgxMDk3NDU1 YWRIZTM>. Acesso em: 09 de jul. de 2015.]

12. Masselli MR, Fregonesi CEPT, de Faria CRS, Bezerra MIS, Junges D, Nishioka TH. índice funcional de Owestry após cirugia para descompressão de raízes nervosas. Fisioter Mov. 2007;20:115-22.

13. Franzblau AN. A primer of statistics for non-statisticians. New York: Harcourt, Brace \& World. 1958.

14. Marcus RL, Addison O, Dibble LE, Foreman KB, Morrell G, Lastayo P. Intramuscular adipose tissue, sarcopenia, and mobility function in older individuals. J Aging Res. 2012;2012:629637.
15. Santos DA, Dawson JA, Matias CN, Rocha PM, Allison DB. Reference values for body composition and anthropometric measurements in athletes. PLoS One. 2014;9(5): e97846.

16. Powers C, Fan B, Borrud LG, Looker AC, Shepherd JA. Long-term precision of dual-energy X-ray absorptiometry body composition measurements and association with their covariates. J Clin Densitom. 2015;18(1):76-85.

17. Larsson I, Lissner L, Samuelson G, Fors H, Lantz H, Naslund I, et al. Body composition through adult life: swedish reference data on body composition. Eur J Clin Nutr. 2015;69(7):837-42.

18. Laskey MA. Dual-energy X-ray absorptiometry and body composition. Nutrition. 1996;12:45-51.

19. Crawford RJ, Filli L, Elliott JM, Nanz D, Fischer MA, Marcon M, et al. Age- and level-dependence of fatty infiltration in lumbar paravertebral muscles of healthy volunteers. Am J Neuroradiol. 2016;37(4):742-8

20. Addison O, Marcus RL, Lastayo PC, Ryan AS. Intermuscular fat: a review of the consequences and causes. Int J Endocrinol. 2014;2014:309570.

21. FosbøI MØ, Zerahn B. Contemporary methods of body composition measurement. Clin Physio Funct Imaging. 2015;35(2):81-97.

22. Hodges PW, James G, Blomster L, Hall L, Schmid A, Shu C, et al. Multifidus muscle changes after back injury are characterized by structural remodeling of muscle, adipose and connective tissue, but not muscle atrophy: molecular and morphological evidence. Spine (Phila Pa 1976) 2015;40(14):1057-71.

23. Mannion AF, Kaser L, Weber E, Rhyner A, Dvorak J, Muntener M, et al. Influence of age and duration of symptoms on fibre type distribution and size of the back muscles in chronic low back pain patients. Eur Spine J. 2000;9(4):273-81.

24. Addison O, Drummond MJ, Lastayo PC, Dibble LE, Wende AR, McClain DA, et al. Intramuscular fat and inflammation differ in older adults: The impact of frailty and inactivity. J Nutr Health Aging. 2014;18(5):532-8.

25. Dahlqvist JR, Vissing CR, Hedermann G, Thomsen C, Vissing J. Fat replacement of paraspinal muscles with aging in healthy adults. Med Sci Sports Exerc. 2017;49(3):595-601.

26. Kelly TL, Wilson KE, Heymsfield SB. Dual energy X-Ray absorptiometry body composition reference values from NHANES. PLoS One. 2009;4(9):e7038.

27. Rahemi H, Nigam N, Wakeling JM. The effect of intramuscular fat on skeletal muscle mechanics: implications for the elderly and obese. J R Soc Interface. 2015;12(109):20150365. 